\title{
Detorgan-3índía:
}

Telaah Pemikiran Kebangsaan

Volume 2 No 2 Tahun 2020 Hlmn. 50-75

Artikel Masuk 3 November 2020 I Artikel Diterima 1 Desember 2020

\section{Menembah Gusti sebagai Basis Adab Menuntut Ilmu}

\author{
Nanda Iqbal Firmansyah, Aji Dedi Mulawarman*
}

Universitas Brawijaya, Jl. MT. Haryono 145, Malang, 65145.

*ajidedim@ub.ac.id

\begin{abstract}
Abstrak
Penelitian ini bertujuan untuk mengetahui pemahaman dan pengalaman berkesadaran mengenai adab menuntut ilmu mahasiswa akuntansi Universitas Brawijaya berbasis konsep menembah Gusti menurut pemikiran HOS Tjokroaminoto, sebagai bagian penting dari praksis tujuan pendidikan akuntansi. Metode penelitian yang digunakan dalam penelitian adalah Hyper-Postphenomenology pada mahasiswa akuntansi yang telah menempuh mata kuliah Etika Bisnis Profesi. Hasil penelitian menunjukkan bahwa semua informan memiliki pemahaman konseptual mengenai pentingnya menembah Gusti yang direpresentasikan melalui adab sebelum ilmu. Hasil yang berbeda terlihat pada tahapan implementasi berkesadaran berkenaan menembah Gusti yang direpresentasikan melalui adab sebelum ilmu, adab dalam berilmu, dan adab di seluruh aktivitas. Hanya satu informan yang telah memiliki kesadaran implementatif berkenaan dengan adab.
\end{abstract}

Kata Kunci: Pendidikan; Adab; Rasa Menembah Gusti; HOS Tjokroaminoto

\section{Abstract}

This study aims to explore the understanding and experience of awareness about the study manners of accounting students of Universitas Brawijaya based on the concept of menembah Gusti (worshipping God) according to the thinking of HOS Tjokroaminoto, as an important part of the practical objectives of accounting education. The research method used in the research is Hyper-Postphenomenology and the objects were students who have taken the Professional Business Ethics course. The results showed that all informants had a conceptual understanding of the importance of menembah Gusti which was represented by manners (adab) before science. Different results can be seen at the awareness implementation stage with regard to worshipping God which is represented through adab before science, manners in knowledge, and manners in all activities. Only one informant has an implementative awareness regarding manners.

Keywords : Education, Adab; Feeling of God Worship, HOS Tjokroaminoto

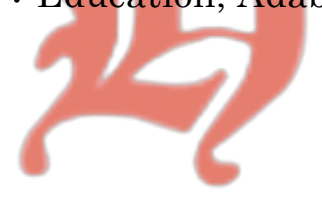




\section{Oetoesan Hindia: Telaah Pemikiran Kebangsaan Volume 2 No 2 Tahun $2020 \mathrm{Hlmn}$. 50-75}

Menurut Undang-Undang Republik Indonesia Nomor 20 Tahun 2003 tentang sistem pendidikan nasional menjelaskan bahwa pendidikan adalah usaha sadar dan terencana untuk menyelenggarakan suatu sistem pendidikan yang meningkatkan keimanan dan ketakwaan dalam rangka mencerdaskan kehidupan bangsa. Pendidikan nasional bertujuan untuk mengembangkan potensi peserta didik agar menjadi manusia yang beriman dan bertakwa kepada Tuhan Yang Maha Esa, berakhlak mulia, cakap, kreatif, mandiri, dan bertanggung jawab. Dalam dunia pendidikan, tugas sekolah maupun perguruan tinggi tidak hanya mendidik para peserta didik agar memiliki pengetahuan intelektual saja, akan tetapi juga harus dibekali dengan pendidikan karakter juga, yaitu pendidikan yang berketuhanan, pendidikan nilai, pendidikan budi pekerti, pendidikan moral, pendidikan watak yang pada akhirnya kembali lagi ke peserta didik sebagai bekal untuk menggunakan pengetahuan dengan baik dan benar. Hal ini senada dengan tujuan pendidikan akuntansi menurut Mulawarman (2008). Mulawarman (2008b, 2008c) menjelaskan tujuan pendidikan akuntansi adalah untuk memberikan nilai-nilai pencerahan dan pembebasan (tazkiyah) serta nilai tambah (value added) bagi mahasiwa dari hegemoni korporasi pendidikan yang bersifat egoistis untuk kepentingan shareholders dan market dalam bentuk sinergi akuntabiltas-moralitas. Akuntabilitas dan moralitas ditujukan bukan hanya kepada stockholders dan kreditur saja, tetapi juga kepada masyarakat dan lingkungan. Dengan demimkian integrasi antara akuntabilitas dan moralitas menjadikan mahasiswa menuju nilai-nilai spiritual yang dapat mencerahkan mahasiswa menuju cinta Allah (Ludigdo dan Mulawarman, 2010). Jadi tujuan pendidikan, khususnya pendidikan akuntansi, tidak boleh terlepas dari nilai-nilai ketuhanan (spiritual). Dengan demikian, mahasiswa ketika lulus dari perguruan tinggi tidak hanya mengandalkan kecerdasan intelektualnya saja tetapi juga harus melibatkan kecerdasan emosi dan kecerdasan spiritual agar menjadi manusia yang cerdas dan berbudi pekerti luhur.

Selama ini pendidikan akuntansi dikembangkan dengan bertumpu pada peningkatan kecerdasan intelektual peserta didik saja, tanpa memerhatikan aspek yang lain seperti kecerdasan emosional dan kecerdasan spiritual yang mana ketiga kecerdasan tersebut tidak bisa dipisahkan (Triyuwono 2010). Hal serupa seperti dijelaskan oleh Ludigdo (2010), menurutnya mata kuliah etika dalam ranah pendidikan akuntansi lebih menekankan pengasahan kemampuan intelektual mahasiswa dengan mengabaikan kemampuan emosi dan kemampuan spiritual. Padahal ketiga kecerdasan tersebut diperlukan oleh mahasiswa agar dapat selalu bekerja sebagai akuntan profesional yang baik dan bertanggung jawab kepada sesama manusia dan Tuhan. Benar apa yang dikemukakan oleh kedua ahli tersebut. Ketika seorang mahasiswa hanya berfokus pada kecerdasan ilmu akuntansi saja tanpa memerhatikan kecerdasan lainnya maka di organissai bahkan di masyarakat nantinya akan mengakibatkan pemahaman materialisme dan egoisme. Ludigdo (2007) membuktikan bahwa suatu praktik etika yang dilakukan oleh individu maupun organisasi tidak terbatas hanya pada individu atau organisasi tersebut. Tetapi konteks 


\section{Adab Menuntut Ilmu... \\ Firmansyah, N.I dan Mulawarman, A.D.}

permasalahannya lebih ke masyarakat yang lebih luas pada umumnya. Hal ini dikarenakan masyarakat merupakan cerminan dari sistem pendidikan saat mereka masih menempuh pendidikan. Boyce (2008) juga menyatakan bahwa akuntansi konvensional harus memasukkan aspek sosial, politik, etis dan lingkungan di mana skandal-skandal perusahaan muncul. Akuntansi yang baik tidak hanya mendidik mahasiswa pada masalah penyadaran berperilaku etis untuk menjadi akuntan professional saja. Tetapi akuntansi yang baik harus memuat secara konseptual bahwa akuntansi dipahami sebagai ilmu sekaligus "values" yang menjadi dasar bagi akuntan menjalankan profesinya dan praktik akuntansi yang beretika. Bahkan Ferguson et al. (2009) telah memeriksa banyak penelitian berkenaan dengan pendidikan akuntansi yang menekankan pada bagaimana ideologi memainkan peran dalam pendidikan akuntansi untuk menanamkan pandangan dunia tertentu. Hal ini membuktikan bahwa ilmu itu tidak hanya berpengaruh pada diri sendiri maupun kelompok tetapi lebih besar lagi yaitu masyarakat secara luas. Ilmu akuntansi selain menguntungkan diri sendiri juga dapat menguntungkan atau merugikan masyarakat luas jika tidak disertai pengetahuan etika yang baik. Dengan demikian dibutuhkanlah pembelajaran yang baik bagi peserta didik untuk menyeimbangkan kecerdasannya.

Pembelajaran yang terstruktur dan pendekatan yang baik itu sangat penting untuk diimplementasikan. Triyuwono (2010) mengemukakan bahwa pembelajaran pendidikan akuntansi dapat diimplementasikan dalam pendekatan muatan aspek sosiospritualitas dengan menggunakan olah akal, olah rasa, dan olah batin. Dalam olah akal berkaitan erat dengan aspek kecerdasan akal atau intelektual (Rational intelligence). Untuk olah rasa lebih menekankan upaya untuk membuat rasa atau perasaan (feelings) menjadi lebih peka. Di dalam olah rasa tidak melalui sebuah proses berpikir, tidak ada proses analisa dan sintesa, yang ada hanya merasakan. Yang terakhir adalah olah batin, yaitu berkaitan erat dengan hubungan manusisa dengan Tuhannya, hubungan ini dapat berupa menyadari, bergurau, dan bertanya kepada Tuhan. Sosiospiritualitas tidak hanya menekankan pada satu kecerdasan saja, tetapi juga diimbangi dengan kecerdasan lainnya. Selain itu terdapat pendekatan dialogis untuk membentuk sikap etis. Selain itu hal yang serupa juga disebutkan oleh Kamayanti. Kamayanti (2012) menjelaskan bahwa untuk membentuk sikap etis diperlukan menginternalisasikan Pancasila melalui pendekatan dialogis. Dalam proses pendekatan dialogis, mahasiswa dapat memunculkan banyak kesadaran (kesadaran ketuhanan atau spritual, keIndonesiaan, kebersamaan dan kemanusiaan, dan berbuat adil). Jadi untuk membentuk sikap etis maka kita dapat menggunakan beberapa pendekatan agar dapat menunjang pembelajaran.

Dari pemaparan di atas permasalahan tersebut salah satunya terjadi karena penuntut ilmu terlalu banyak menggeluti ilmu sampai lupa mempelajari adab, lebih memprioritaskan ilmunya daripada adab yang dimiliki. Dalam artian lain mereka lebih mementingkan IQ (kecerdasan intelektual) dan mengesampingkan EQ (kecerdasan emosional) serta SQ (kecerdasan spiritual). Hal ini bisa tercermin dari perilaku para pelajar, mereka ingin untuk memperoleh nilai yang tinggi dengan cara yang tidak dibenarkan seperti mencontek saat ujian. Dalam artikel berita liputan6 (2012) diberitakan bahwa saat pelaksanaan Ujian Nasional di berbagai daerah pada 


\section{Oetoesan Hindia: Telaah Pemikiran Kebangsaan}

Volume 2 No 2 Tahun $2020 \mathrm{Hlmn}$. 50-75

hari kedua sejumlah siswa tertangkap ketika sedang mencontek dan bertukar jawaban ujian. Contekan tersebut dibawa siswa dari HP mereka. Dari kejadian tersebut terlihat bahwa mempelajari adab dahulu lebih penting daripada mempelajari ilmu terlebih dahulu. dengan adab maka ilmu akan mudah untuk dipelajari. Dengan memerhatikan adab maka akan mudah meraih ilmu. Sedikit perhatian pada adab maka ilmu akan disia-siakan (Tuasikal, 2014).

Adab atau moral yang baik memang sangat penting dalam kehidupan sosial. Jika kita tidak memiliki adab yang baik maka kita memandang setiap praktik akuntansi atau bisnis itu hanya untuk memaksimalkan keuntungan (materialistik) tanpa memerhatikan aspek sosial lainnya. Contoh dalam praktik akuntansi seperti penelitian yang dilakukan oleh Moneva et al. (2006) mendeteksi bahwa pelaporan sustainability yang dikeluarkan oleh The Global Reporting Initiative (GRI) untuk membantu organisasi melaporkan kinerja ekonomi, sosial dan lingkungan serta meningkatkan akuntabilitas misalnya, ternyata hanya dijadikan perusahaan sebagai alat "pelaporan basa basi" saja. Bahkan Chwastiak dan Young (2003) telah membuktikan bahwa pembuatan laporan tahunan perusahaan sebenarnya ditujukan sebagai alat melakukan praktik tidak etis untuk kepentingan corporate hegemony. Laporan Tahunan hanyalah ekspresi kepentingan perusahaan memaksimalkan keuntungan tanpa peduli aspek sosiallingkungan-spiritualitas.

Adab merupakan suatu konsep kunci yang pada hakikatnya inti dari proses pendidikan Islam. Hal ini dikarenakan setiap kegiatan penting seperti ibadah dan muamalah, di situ pasti terdapat unsur pentingnya adab (Al-Attas, 1996). Selain itu pentingnya adab bagi manusia adalah untuk menuntun manusia kepada tingkah laku yang baik dan menjauhkan diri dari tingkah laku yang buruk, serta dapat mengatur dan mengarahkan manusia kepada fitrahnya yaitu menyembah Allah Yang Maha Esa. Ada banyak ulama atau tokoh yang membahas mengenai perilaku, moral, atau adab. Salah satunya adalah pemahaman adab menurut HOS Tjokroaminoto.

Di dalam bukunya yang berjudul Memeriksai Alam Kebenaran, HOS Tjokroaminoto menyebutkan bahwa untuk memiliki adab, moralitas, atau budi pekerti yang baik menurut HOS Tjokroaminoto manusia harus memiliki rasa menembah Gusti. Dengan kata lain, rasa menembah gusti memiliki arti bahwa segala aktivitas kegiatan harus diniatkan untuk beribadah. Dalam syarah bukunya Memeriksai Alam Kebenaran, Mulawarman (2019) membahas tentang memeriksai alam kebenaran sebagai refleksi Islam dalam ruang kedirian, kemasyarakatan, dan kenegaraan tidak pernah lepas dengan apa yang disebut beliau sebagai bentuk implementasi nilai Tauhid dengan rasa Menembah Gusti di segala aspek kehidupan ini. Menembah Gusti adalah syarat bagi setiap muslim dalam mengarungi kehidupan dunia yang fana ini hingga ke alam akhirat nanti. Setaip muslim tidak hanya dituntut untuk mempelajari ilmu saja, ilmu dunia maupun ilmu agama, tetapi lebih dari itu, mereka dituntut untuk mengamalkan ilmu yang mereka miliki dalam kehidupan ini sebagai bekal nantinya. Dalam mengamalkan ilmu tersebut harus dilandasi dengan pemahaman tentang nilai-nilai Ketuhanan. Menembah Gusti secara umum memiliki dua gagasan 


\section{Adab Menuntut Ilmu... \\ Firmansyah, N.I dan Mulawarman, A.D.}

utama, yaitu gagasan kecerdasan kemanusian saat kita memahami nilai-nilai Ketauhidan dan kecintaan tanpa batas yang menjadi kecerdasan Ilahiyah yang mana mengasah hati, moralitas, perilaku, budi pekerti untuk mendorong ummat ini menjadi sempurna.

\section{Metode}

Jenis penelitian yang digunakan pada penelitian ini adalah penelitian kualitatif. Dalam perkembangannya ada beberapa istilah mengenai penelitian kualitatif. Menurut Moleong (2005:6) mendefinisikan penelitian kualitatif adalah penelitian yang bermaksud untuk memahami fenomena tentang apa yang dialami oleh subjek penelitian misalnya perilaku, motivasi, tindakan, dan lain-lain secara holistic dan dengan cara deskriptif dalam bentuk kata-kata dan bahasa, pada suatu konteks khusus yang alamiah dan dengan memanfaatkan berbagai metode alamiah. Menurut Sugiyono (2011), metode penelitian kualitatif adalah metode penelitian yang berlandaskan pada filsafat post positivism, digunakan untuk meneliti pada kondisi objek yang alamiah (sebagai lawannya eksperimen), di mana peneliti adalah sebagai instrumen kunci, pengambilan sampel sumber data dilakukan secara purposive dan snowball, teknik pengumpulan dengan tri-anggulasi (gabungan), analisis data bersifat induktif atau kualitatif, dan hasil penelitian kualitatif lebih menekankan makna dari pada generalisasi.

Dalam penelitian mengenai pemahaman adab menuntut ilmu bagi mahasiswa akuntansi FEB UB, peneliti menggunakan pendekatan fenomenologi yang bersifat kualitatif, dengan paradigma intrepretif sebagai payung penelitian. Fenomenologi merupakan pandangan berpikir yang menekankan pada fokus kepada pengalamanpengalaman subjektif manusia dan interpretasi-interpretasi dunia. Studi fenomenologi berasumsi bahwa setiap individu mengalami suatu fenomena dengan segenap kesadarannya. Dengan ini diharapkan dapat menggali kesadaran terdalam para subjek mengenai pengalamannya dalam suatu peristiwa. Paradigma intrepretif ini digunakan untuk memahami (to understand), bukan untuk menjelaskan (to explain) dan memprediksi (to predict). Paradigma interpretif berasumsi bahwa realitas sosial keberadaannya tidak konkret, melainkan pengalaman pengalaman.

Dalam penelitian fenomenologi menekankan pada subjektifitas dan pengungkapan dari pengalaman dengan beberapa komponen konseptual, yaitu: fenomena, kesadaran, noema, noesis, epoche, konstitusi, kesadaran, dan reduksi. Seluruh komponen tersebut saya gunakan dalam memahami keterkaitan pemahaman adab menuntut ilmu mahasiswa akuntansi FEB UB dalam perspektif pemikiran HOS Tjokroaminoto. Penelitian mengenai adab menuntut ilmu dirasa sangat cocok untuk menggunakan fenomenologi dikarenakan objek penelitian merupakan suatu aktivitas yang dilakukan oleh individu. Objek penelitian yang akan diteliti dalam penelitian ini adalah empat orang mahasiswa S1 akuntansi FEB UB. Dari keempat informan tersebut semuanya telah menempuh mata kuliah Etika Bisnis. Pemilihan informan tidak hanya melalui intuisi pribadi dari penulis semata, tetapi juga melibatkan pihak luar, dalam hal ini rekomendasi dari dosen pembimbing. 


\section{Oetoesan Hindia: Telaah Pemikiran Kebangsaan \\ Volume 2 No 2 Tahun $2020 \mathrm{Hlmn}$. 50-75}

Penelitian ini menggunakan Hyper-postphenomenology yang menggabungkan fenomenologi Islam dan posfenomenologi. Fenomenologi Islam mengambil pemikiran dari tokoh Islam Indonesia yaitu HOS Tjokroaminoto. Posfenomenologi diartikan bahwa alat telah menubuh (embodied) pada individu. Oleh karena itu, meletakkan alat media sosial (Facebook, Whatsapp, Instagram, dll) sebagai instrumen/techne yang akan mendasari penyingkapan kebenaran (aletheia) dari mahasiswa FEB UB yaitu untuk kepentingan tertentu. Dalam postphenomenology, pada dasarnya teknologi (techne) dimaknai sebagai penyingkapan kebenaran (aletheia). Metode yang digunakan untuk memahami makna alat ini adalah dengan poesis, yaitu mengungkap makna yang sebelumnya belum ada; karena campur tangan manusia maka makna menjadi mengada. Postphenomenology berada pada asumsi bahwa noema (apa yang tampak dan terbaca) dan noesis (apa yang disadari melalui pengalaman) merupakan saling kelindan dengan keberadaan teknologi yang menubuh pada budaya.

Gambar 1. Proses Embodiment - Analisis Post-Phenomenology

$-\left\{\begin{array}{l|}\hline \multicolumn{1}{|c|}{\text { Body One }} \\ \hline \text { Mikro persepsi: } \\ \text { Mahasiswa } \\ \text { Akuntansi FEB } \\ \text { UB }\end{array}\right.$

$\left.\begin{array}{|l|}\hline \text { Instrumen/Techne } \\ \hline \text { Smartphone } \\ \text { Media Sosial: } \\ \text { FB, WA, IG, dll }\end{array}\right\}$

\begin{tabular}{|l|}
\hline \multicolumn{2}{|c|}{ Body Two } \\
\hline Makro persepsi: \\
Menembah Gusti \\
sebagai \\
Representasi Adab \\
\hline
\end{tabular}

1. Mengidentifikasi media sosial (FB, WA, IG) sebagai suatu alat (techne) yang memiliki nilai tertentu. Nilai tersebut merupakan kebenaran (aletheia) yang diungkapkan melalui status di media sosial oleh individu tersebut.

2. Mendukung temuan dengan mengidentifikasi noema, yaitu kesadaran yang mulai tampak dan memaparkan noesis, yaitu kesadaran yang muncul akibat adanya pengalaman dari para pengguna techne, dalam hal ini mahasiswa akuntansi FEB UB. Mereka merupakan Body One yang menegaskan bahwa techne merupakan suatu alat yang menubuh (embodied) pada Body One yang digunakan untuk kepentingan Body Two.

3. Menjelaskan bentuk alethia, yang mana techne memang telah menubuh pada Body One.

Penelitian ini menggunakan hyper-post phenomenology sebagai metode analisis. Postphenomenology atau yang juga disebut dengan fenomenologi instrumentalisasi adalah metode yang diperkenalkan oleh Ihde. Dalam pandangannya, dijelaskan bahwa instrument dan sains adalah dua hal yang tidak terpisah, tetapi embodied atau menubuh. Bagi Ihde, fenomenologinya bertumpu pada persepsi bahwa teknologi (alat) telah tertanam pada budaya, dan melalui alat tersebut, manusia melakukan aktivitasnya (Kamayanti, 2017).

Penelitian ini menggunakan teknik analisis data yang sesuai dengan pendekatan studi fenomenologi sebagaimana dijabarkan oleh Sanders (1982). Empat tahap dalam 
Adab Menuntut Ilmu...

Firmansyah, N.I dan Mulawarman, A.D.

analisis fenomenologi: Tahapan pertama, mendeskripsikan fenomena dari hasil wawancara yang telah direkam. Transkrip wawancara mengidentifikasi dan menjelaskan kualitas dari pengalaman dan kesadaran informan. Tahapan kedua, mengidentifikasi tema yang muncul dari deskripsi pada tahap pertama. Tahapan ketiga, pengembangan noema dan noesis Tahapan keempat, mengabstrakasikan esensi dari korelasi antara noema dan noesis. Proses abstraksi ini disebut juga dengan eidetic reduction.

\section{Hasil dan Pembahasan}

HOS Tjokroaminoto dan Pendidikan Karakter. Di sini peneliti ingin mengetahui pemahaman para informan mengenai HOS Tjokroaminoto. Apakah sejarah perjuangan kemerdekaan Indonesia yang dilakukan oleh HOS Tjokroaminoto ini yang merupakan penggerak atau pelopor kemerdekaan Indonesia ini masih diingat oleh para informan atau sudah dilupakan. Ketika peneliti mewawancarai keempat informan, mereka masih mengingat HOS Tjokroaminoto dari pelajaran sekolah dulu. Hafidz menjawab:

"HOS Tjokroaminoto setauku salah satu mentor yang berpengaruh terhadap menciptakan beberapa tokoh bangsa. Seingetku salah satunya Soekarno. Beliau juga kalau tidak salah memiliki andil besar terhadap organisasi Sarekat Islam, salah satu organisasi Islam terbesar yang diawali dengan Sarekat Dagang, yang pada akhirnya berpengaruh besar terhadap kemerdekaan Indonesia. Aku taunya dari sejarah saat sekolah dulu dan situs internet."

Dari noema yang tampak pada Hafidz, dia mengetahui HOS Tjokroaminoto saat masih sekolah dulu dan dari situs internet. Menurutnya HOS Tjokroaminoto merupakan mentor yang berpengaruh untuk menciptakan tokoh bangsa diantaranya adalah Ir Soekarno. Dan beliau merupakan pelopor dalam organisasi Sarekat Islam yang merupakan organisasi Islam terbesar dalam kemerdekaan Indonesia. Berikutnya untuk mendapatkan kesadaran yang lebih mendalam dan untuk mengembangkan epoche peniliti bertanya lebih lanjut terkait moral HOS Tjokroaminoto yang mana presiden pertama Republik Indonesia berguru padanya. Hafidz menjawab:

"Jadilah orang yang tidak mudah menyerah. Hidup dengan idealism pantang menyerah untuk tujuan yang lurus. Kemudian, bersabar dalam memperjuangkan tujuan tersebut karena seperti HOS Tjokroaminoto beliau berjuang tidak memikirkan apakah akan berhasil, atau akankah ada pengaruhnya, tetapi berjuang ya berjuang aja dengan ikhlas. Kalau beliau sudah berpikir apakah akan berhasil lalu dikalkulasikan, pasti perjuangannya mudah melempem ketika menerima kenyataan bahwa musuh SI sangat banyak pada saat itu. Perlu berpandangan baik terhadap masa depanlah terlepas dari kondisi sulit saat ini." 


\section{Oetoesan Hindia: Telaah Pemikiran Kebangsaan \\ Volume 2 No 2 Tahun $2020 \mathrm{Hlmn}$. 50-75}

Kesadaran yang diungkapkan oleh Hafidz dari pengetahuannya terkait moral yang harus dimiliki generasi ini dari tokoh nasional HOS Tjokroaminoto adalah harus memiliki idealism pantang menyerah, bersabar dalam memperjuangkan tujuan masa depan, ikhlas dalam melakukan perjuangan. Menurutnya kita harus memiliki pandangan yang baik akan masa depan dan pantang menyerah dalam menghapai segala rintangan untuk mencapai tujuan yang diinginkan. Lalu peneliti melanjutkan pertanyaan terkait pemahaman atau praktik moral generasi ini dari HOS Tjokroaminoto dari sudut pandang Hafidz. Dia mengungkapkan:

"Menurutku belum sih. Generasi sekarang itu tidak punya idealisme yang tepat. Terlalu praktis, apa yang menguntungkan itulah yang dibela."

"iya, untuk kepentingan diri sendiri, saudara, dan keluarga. Makanya politik dinasti kan banyak. Hahaha. Generasi sekarang untuk menyuarakan suaranya banyak takutnyalah. Gimana kata orang, gimana kata sebelah dan sebagainya. Berbeda dengan zamannya beliau."

Intentional analysis dari Hafidz menunjukkan bahwa HOS Tjokroaminoto merupakan seorang mentor yang berjasa dalam melahirkan tokoh-tokoh nasional yang mana moral dari beliau masih belum diterapkan pada sebagian generasi ini. Kesadaran yang lebih mendalam (noesis) dari Hafidz menunjukkan bahwa dia beranggapan generasi saat ini masih belum memiliki moral yang sesuai dengan HOS Tjokroaminoto dikarenakan menurutnya belum memiliki idealisme yang tepat. Kesimpulan yang dapat peneliti abstraksikan (eidetic reduction) dari noema dan noesis Hafidz adalah untuk menjadi tokoh besar kita harus memiliki idealism yang kuat, pantang menyerah dan ikhlas dalam memperjuangkan tujuan kita. Kita tidak boleh memiliki sifat egois yang dicerminkan dengan apa yang lebih menguntungkan baginya itu yang dibela. Menurutnya generasi ini berbeda dengan zaman beliau yang penuh semangat membela aspirasi rakyat kecil untuk kemerdekaan bangsa Indonesia dari cengkeraman penjajah. Kita masih takut untuk menyuarakan pendapat kita karena tekanan dari pihak lain. Menurutnya Kita dapat menyuarakan pendapat kita jika memang benar dan tidak takut terhadap perkataan orang lain tanpa mengurangi rasa hormat terhadap pihak lain. Sementara itu Ahmad juga berpendapat yang mana tidak jauh berbeda dengan pendapat Hafidz. Ahmad menjelaskan:

"Setauku HOS Tjokroaminoto itu seorang bangsawan yang memiliki
pemikiran yang banyak dianut oleh pendiri bangsa ini. Dan juga Presiden
pertama kita Ir Soekarno berguru kepada beliau. Aku tau HOS
Tjokroaminoto dari bukunya yang berjudul Islam dan Sosialisme."

Dari noema yang diungkapkan oleh Ahmad, dia mengetahui HOS Tjokroaminoto merupakan bangsawan Jawa yang pemikirannya banyak dianut oleh tokoh-tokoh 


\title{
Adab Menuntut Ilmu... Firmansyah, N.I dan Mulawarman, A.D.
}

besar Bangsa Indonesia ini, misalnya seperti Presiden Soekarno. Ahmad mengetahui HOS Tjokroaminoto dari buku yang berjudul Islam dan Sosialisme. Dari analisis teksturan tersebut, peneliti ingin mendalami kesadaran yang dimiliki oleh Ahmad. Peneliti menanyakan mengenai moral yang dimiliki oleh HOS Tjokroaminoto. Ahmad menjawab:

\begin{abstract}
"Banyak perbuatan moral yang baik dari beliau yang patut kita contoh. Diantaranya itu kita harus memiliki rasa penuh semangat untuk memperjuangkan apa yang kita inginkan. Misalnya saat kuliah kita harus semangat belajar dan menyelesaikan tugas meskipun tugasnya itu terlalu banyak."
\end{abstract}

Pernyataan tersebut mengungkapkan bahwa Ahmad berpendapat kita harus memiliki rasa penuh semangat untuk mencapai tujuan yang kita inginkan di masa depan. Ketika masih kuliah kita harus penuh semangat dalam belajar dan menyelesaikan tugas yang diberikan oleh para dosen. Dari ungkapan tersebut, peneliti ingin mendapatkan noesis dari Ahmad dengan menanyakan apakah generasi ini memiliki moral seperti HOS Tjokroaminoto. Ahmad menjawabnya:

\begin{abstract}
"Belum, aku kasih contoh saja di kelas masih banyak yang sibuk dengan HP sendiri dan juga masih bengong sendiri ketika diajar dan kalau ditanya banyak yang diam. Jadi pikran mereka gak fokus ke kelas. Tapi masih banyak juga kok yang memperhatikan dengan sungguh-sungguh.”
\end{abstract}

Intentional analysis dari Ahmad menunjukkan bahwa dia beranggapan HOS Tjokroaminoto adalah seorang bangsawan yang banyak melahirkan tokoh nasional melalui pendidikan dan pemikirannya. Moral dari HOS Tjokroaminoto masih belum diterapkan pada sebagian mahasiswa saat kegiatan perkuliahan dikarenakan sebagian ada yang kurang memerhatikan pelajaran. Kesadaran yang lebih mendalam (noesis) Ahmad mengungkapkan bahwa di kelas masih terdapat mahasiswa yang belum memerhatikan pelajaran dengan saksama. Dari sini peneliti dapat mengabstraksikan (eidetic reduction) dari studi fenomenologis dengan Ahmad adalah HOS Tjokroaminoto merupakan seorang bangsawan yang memiliki pemikiran luar biasa sampai-sampai presiden pertama Republik Indonesia berguru kepadanya. Beliau memiliki moral yang baik dan menjadi pelopor dalam kemerdekaan Republik Indonesia dengan semangatnya untuk memerdekakan bangsa ini. Menurut Ahmad perbuatan tersebut masih belum dimiliki oleh sebagian mahasiswa karena mereka masih belum memerhatikan pelajaran di kelas atau sibuk sendiri dengan smartphone-nya. Meskipun demikian menurutnya masih banyak juga mahasiswa yang penuh semangat memerhatikan dosen ketika menerangkan karena mereka memperjuangkan apa yang mereka inginkan di masa yang akan datang.

Lebih lanjut peneliti ingin mengungkap kesadaran dari informan lainnya. Maulana yang merupakan mahasiswa S1 Akuntansi berpendapat mengenai 


\section{Oetoesan Hindia: Telaah Pemikiran Kebangsaan \\ Volume 2 No 2 Tahun $2020 \mathrm{Hlmn}$. 50-75}

pengetahuannya tentang HOS Tjokroaminoto dan dari mana dia mengetahuinya. Dia menjelaskan:

"Dia adalah guru besar yang menjadi cikal bakal Bung Karno berpolitik.

Aku tahu beliau dari pelajaran waktu sekolah dulu dan dari youtube."

Dari noema yang tampak yang diungkapkan oleh Maulana. Menurutnya HOS Tjokroaminoto merupakan guru besar yang menjadikan Bung Karno seorang politikus. Maulana mengetahui HOS Tjokroaminoto dari pelajaran di sekolahnya dulu dan dari platform youtube. Ketika peneliti menanyakan apa yang membuat presiden pertama Republik Indonesia berguru kepada beliau dan moral apa yang dapat dijadikan teladan, Maulana menjawab:

"Karena perjuangannya dalam mengusir penjajah. Untuk moral yang dapat kita petik yaitu semangat kesatuan membela bangsa dan jangan melupakan sejarah."

Dari noema yang dikemukakan oleh Maulana di atas, menurut Maulana tokoh besar seperti HOS Tjokroaminoto harus memiliki rasa semangat kesatuan untuk membela tanah air agar menjadi inspirasi bagi kaum muda untuk melanjutkan pergerakannya. Dan kita tidak boleh melupakan sejarah kemerdekaan karena untuk mengenang jasa para pahlawan kemerdekaan Indonesia. Berikutnya peneliti ingin mengupas kesadaran yang lebih mendalam (epoche) dari Maulana. Akhirnya peneliti menanyakan tentang apakah generasi sekarang ini sudah mencontoh moral HOS Tjokroaminoto. Maulana mengungkapkan:

"Jelas belum karena KKN masih merajalela. Itu karena orang-orang yang KKN rela membohongi rakyatnya demi ambisi pribadi dan itu justru bukannya membela bangsa dan negara justru merusak negara itu sendiri. Selain itu poin kenapa sekarang banyak orang masa bodoh sama sejarah khususnya politik, mungkin karena tidak peduli atau pemerintahan dari dulu sampai sekarang yang mungkin bagi kebanyakan orang masih terlalu diintervensi asing dalam membuat suatu keputusan."

Dari pernyataan tersebut kita, Maulana mengungkapkan sebagian generasi ini masih belum memiliki moral yang baik seperti HOS Tjokroaminoto karena masih terdapat banyaknya kasus korupsi di negeri ini. Selain itu menurut Maulana sebagian orang merasa bahwa sejarah itu tidak penting. Selanjutnya peneliti menanyakan lebih jauh tentang sifat egoism-materialistik dari pernyataan dia terkait KKN tersebut. Maulana menjawab: "iya umumnya demikian. Karena uang bisa mengubah hati seseorang."

Intentional analysis dari Maulana menunjukkan bahwa dia beranggapan perjuangan yang dilakukan oleh para pejuang kemerdekaan Indonsia tidak boleh 


\section{Adab Menuntut Ilmu... Firmansyah, N.I dan Mulawarman, A.D.}

dilupakan dan kita menghormati para pahlawan bangsa ini dengan tidak korupsi meskipun uang bisa mengubah hati seseorang. Kesadaran yang lebih mendalam (noesis) Maulana mengungkapkan bahwa dengan uang hati seseorang bisa berubah. Dengan uang, moral yang baik akan berubah menjadi materialistic-oriented. Dari sini peneliti dapat mengabstraksikan (eidetic reduction) dari studi fenomenologis dengan Maulana adalah seorang tokoh besar pasti lahir dari guru yang besar. Menurutnya generasi ini seharusnya mencontoh adab beliau dalam membela bangsa ini dan tidak melupakan jasa para pahlawan negeri ini. Untuk menjadi orang yang beradab seperti HOS Tjokroaminoto, kita tidak boleh mengkhianati rakyat dengan cara mengkorupsi uang rakyat untuk kepentingan individu maupun kelompok.

Ketika peneliti memaknai kesadaran dari Dewi, ungkapan yang muncul hampir sama dengan ketiga informan di atas. Tetapi Dewi beranggapan bahwa untuk generasi sekarang mungkin sudah banyak yang melakukan perbuatan seperti HOS Tjokroaminoto. Sama seperti ketiga informan di atas peneliti menanyakan terlebih dahulu pengetahuan Dewi mengenai HOS Tjokroaminoto. Dewi menjawab:

"Bapak Tjokroaminoto setauku seorang guru untuk tokoh-tokoh
berpengaruh kayak bapak Sukarno. Beliau juga teladan yang baik untuk
masyarakat. Aku taunya pas baca sekilas dari internet."

Noema yang tampak dari Dewi adalah dia mengetahui HOS Tjokroaminoto merupakan seorang guru yang berpengaruh pada bangsa ini seperti Ir Soekarno. Untuk moral yang dapat kita ambil dari beliau menurutnya adalah kita harus berbuat baik untuk menjadi cahaya masyarakat. Kesadaran awal yang tampak pada Dewi tidak jauh berbeda dengan noema yang dikemukakan oleh ketiga informan lainnya. Kemudian peneliti menanyakan pertanyaan lebih jauh untuk menggali noesis dari Dewi. Peneliti menanyakan terkait apakah moral HOS Tjokroaminoto sudah diterapkan di zaman ini. Dewi mengatakan:

“...untuk generasi sekarang ini mungkin sudah banyak yang memiliki moral seperti beliau, namun tidak sedikit juga yang masih belum dan masih belajar."

Noesis yang diungkapkan oleh Dewi sedikit berbeda dengan ketiga informan lainnya. Noesis Dewi mengatakan untuk generasi sekarang mungkin saja sudah banyak yang memiliki moral seperti HOS Tjokroaminoto, tetapi juga ada yang belum dan masih belajar untuk memiliki moral yang baik. Dari noema dan noesis Dewi yang dapat peneliti abstraksikan adalah HOS Tjokroaminoto merupakan seorang guru dan tokoh besar seperti Ir Soekarno. Selain itu beliau juga merupakan pendiri Sarekat Islam. Dewi mengunkapkan bahwa perbuatan baik yang dapat kita ambil dari beliau adalah kita harus menjadi teladan yang baik dan menjadi cahaya masyarakat. Kesadaran Dewi juga mengungkapkan bahwa untuk generasi sekarang ini mungkin sudah banyak yang memiliki moral baik seperti HOS Tjokroaminoto, namun juga ada yang masih belum atau masih dalam tahap belajar. 


\title{
Oetoesan Hindia: Telaah Pemikiran Kebangsaan \\ Volume 2 No 2 Tahun $2020 \mathrm{Hlmn}$. 50-75
}

Penjelasan yang diungkapkan oleh keempat informan di atas hampir sama semuanya. Hanya berbeda dalam mengungkapkan Adab yang dimiliki oleh HOS Tjokroaminoto menurut pemahaman yang mereka peroleh di waktu sekolah dahulu atau internet. Mereka semua mengungkapkan bahwa HOS Tjokroaminoto adalah seorang guru besar atau mentor yang bisa menjadikan muridnya menjadi tokoh besar bahkan pahlawan kemerdekaan bangsa ini. Beliau mencurahkan jiwanya untuk berkontribusi dalam kemerdekaan Bangsa Indonesia.

Pentingnya Adab Sebelum Menuntut Ilmu. Ketika peneliti menanyakan tentang lebih penting mana antara adab dan ilmu. Ahmad mengungkapkan:

\begin{abstract}
"Keduanya penting. Sepemahamanku adab itu harus didahulukan daripada ilmu. Soalnya orang yang berilmu saja tanpa memperhatikan adab maka orang itu bisa tersesat akan ilmunya. Jadi pahamilah adab terlebih dahulu sebelum menuntut ilmu."
\end{abstract}

Dari noema yang diungkapkan oleh Ahmad, dia berpendapat bahwa adab dan ilmu itu sama-sama penting. Tetapi adab harus didahulukan daripada ilmu agar orang tersebut tidak tersesat akan ilmu yang dia peroleh. Memang ada benarnya ketika kita mencari ilmu tanpa didasari adab yang baik saat kita menuntut ilmu maka ilmu yang kita peroleh bisa jadi akan sia-sia atau menjadikan kita orang yang sombong. Selanjutnya peneliti ingin mengembangkan pertanyaan (epoche). Peneliti menanyakan lebih lanjut terkait adab mahasiswa di kelas etika bisnis menurut pengamatan dan pengalaman Ahmad saat menempuh mata kuliah tersebut. Ahmad menjawab:

"Belum. Buktinya banyak yang masih mainan HP dan juga masih bengong sendiri ketika diajar dan kalau ditanya banyak yang diam. Jadi pikran mereka gak fokus ke kelas. Tapi masih banyak juga kok yang memperhatikan dengan sungguh-sungguh.”

Dari pernyataan di atas, Ahmad mengungkapkan bahwa menurut pengamatan dan pengalamannya di kelas masih ada mahasiswa yang masih memainkan HP-nya ketika dosen sedang mengajar di depan kelas. Tetapi menurut pengamatannya masih banyak juga yang memerhatikan dosen ketika sedang menerangkan. Dari pernyataan yang dikemukakan oleh Ahmad tersebut, kemudian peneliti ingin memperdalam ungkapan dari Ahmad. Peneliti menanyakan akibat dari tidak mengindahkan adab yang baik ketika menjalankan sebuah bisnis. Ahmad menjawab:

"Contohnya seperti ekspansi perusahaan dengan mengeksploitasi SDA besar-besaran dengan menggusur tanah rakyat sekitar, memanipulasi laporan keuangan seperti Enron. Itu semua menurutku kurang beretika meskipun mereka dengan itu memperoleh laba yang besar.” 


\section{Adab Menuntut Ilmu... \\ Firmansyah, N.I dan Mulawarman, A.D.}

Noesis yang diungkapkan oleh Ahmad mengatakan bahwa perbuatan seperti mengeksploitasi SDA besar-besaran dengan menggusur tanah rakyat sekitar, serta memanipulasi laporan keuangan seperti Enron merupakan perbuatan yang tercela. Intentional analysis dari Ahmad menunjukkan bahwa adab diperlukan terlebih dahulu karena untuk membentengi kita agar tidak melakukan perbuatan yang tidak etis ketika menjalankan sebuah bisnis. Dari noema dan noesis tersebut kita dapat mengabstraksikan (eidetic reduction) bahwa menuntut ilmu sangatlah penting untuk bekal pendidikan, tetapi terlebih dahulu harus dibarengi dengan adab yang baik agar ilmu yang diperoleh menjadi bermanfaat. Selain itu dari pengamatan Ahmad di kelas ketika kita tidak memerhatikan adab dalam menuntut ilmu maka kita akan melakukan hal yang menurut kita biasa saja tetapi itu merupakan suatu hal yang kurang beradab seperti memainkan HP saat dosen sedang menerangkan di depan kelas. Disamping itu ketika seseorang mempunyai adab yang baik maka sebelum memulai kegiatan bisnisnya, orang tersebut akan memerhatikan terlebih dahulu dampak yang akan diakibatkan dari proses bisnisnya tersebut.

Di sisi lain, senada dengan Ahmad. Maulana memaknai adab dan ilmu merupakan sesuatu yang penting. Ketika peneliti berdiskusi dengan Maulana terkait adab dan ilmu. Maulana mengungkapkan:

"Kalau kata aku lebih penting adab. Aku gak bilang ilmu gak penting yak.

Orang kalo punya hati tanpa dikasih ilmunya bisa berbuat baik."

Pernyataan awal (noema) yang diungkapkan oleh Maulana menyatakan bahwa dia berpendapat adab lebih penting daripada ilmu. Jika kita memiliki adab maka dengan sendirinya kita akan mampu untuk berbuat baik terutama di lingkungan sekitar kita. Dari sini peneliti mengembangkan sebuah epoche untuk mengupas kesadaran yang lebih mendalam. Peneliti menanyakan apakah sudah dipraktikkan adab menuntut ilmu di kelas. Maulanapun mengungkapkan:

"Menurutku kalau soal sudah dipraktikkan atau belum itu kembali ke masing-masing individu. Biasanya barisan belakang suka asik sendiri memainkan HP-nya. Kalau barisan tengah ke depan lebih fokus ke depan, mungkin jarak antara pengajar dengan yang diajar cukup pas untuk dipantau."

Dari pernyataan Maulana di atas, dia mengungkapkan bahwa menurutnya melalui pengalaman yang Maulana miliki di dalam kelas terdapat berbagai macam tipe mahasiswa. Ada yang memerhatikan dosen saat menerangkan dan ada yang belum. Hal ini dikarenakan menurut pengamatannya, posisi tempat duduk memengaruhi perilaku para mahasiswa. Selanjutnya peneliti bertanya lebih jauh tentang mata kuliah etika bisnis di perkuliahan apakah penting untuk diterapkan. Mata kuliah etika bisnis merupakan mata kuliah yang didesain untuk membekali mahasiswanya untuk berperilaku etis ketika mereka sudah memasuki dunia kerja. Peneliti ingin mengetahui pendapat dari Maulana tentang hal tersebut. Maulana menjelaskan: 


\section{Oetoesan Hindia: Telaah Pemikiran Kebangsaan \\ Volume 2 No 2 Tahun 2020 Hlmn. 50-75}

"Jelas penting. Begini, sebelum memulai bisnis harusnya kita tahu dong bagaimana kita dalam berbisnis. Kita tidak merugikan konsumen, klien, ataupun lingkungan di sekitar kita. Kalau kamu pernah nonton film Sexy Killers di youtube, kamu akan melihat berapa banyak orang meninggal karena pengelolaan buangan asap dari PLTU yang salah urus. Gak cuma itu, rumah di sekitaran galian tambang batu bara yang kelak dijadikan bahan utama untuk dijadikan listrik dari PLTU sampai ke rumah-rumah kita, terkena debu dari tambang batu bara. Bayangkan bisnis sebesar itu saja orang-orang cuek terhadap etika bisnis. Jadi dalam sekala besar seperti itu fatal karena merugikan banyak orang."

Intentional analysis dari Maulana menunjukkan bahwa adab diperlukan terlebih dahulu karena untuk membentengi kita agar tidak melakukan perbuatan yang tidak etis khususnya dalam berbisnis. Kesadaran yang lebih mendalam (noesis) yang diungkapkan oleh Maulana menyatakan bahwa ilmu tentang etika bisnis sangat penting karena dengan itu kita bisa mengetahui perbuatan mana yang merugikan dan tidak merugikan berbagai pihak. Dari sini dapat peneliti abstraksikan (eidetic reduction) bahwa menurut Maulana Adab lebih penting daripada ilmu. Dengan adab orang bisa melakukan suatu kebaikan meski belum memiliki ilmunya. Dari pengalaman dan pengamatan Maulana di kelas, dia mengamati bahwa terdapat mahasiswa yang masih memainkan HP-nya ketika dosen sedang menerangkan di depan kelas. Hal ini dikarenakan mereka berada dibarisan belakang. Berbeda dengan mereka yang ada dibarisan tengah dan depan. Mereka lebih memerhatikan dosen ketika menerangkan. Menurut pandangan Maulana, perusahaan yang dibekali dengan moral yang baik sebelumnya pasti tidak akan merusak lingkungan dan hanya mementingkan laba saja seperti dalam film dokumenter "Sexy Killers".

Sementara itu informan lainnya, Dewi, mengungkapkan perihal yang sama. Adab dan ilmu itu sama-sama penting. Ketika peneliti bertanya kepadanya terkait adab dan ilmu serta lebih didahulukan mana antara adab dan ilmu. Dewi menjawab:

"Dua-duanya penting, tapi yang harus didahulukan adab karena seseorang yang lagi menuntut ilmu itu agar ilmunya yang sedang dipelajari dapat berkah, agar punya tata krama."

Dari noema yang diungkapkan oleh Dewi, dia berpendapat bahwa adab dan ilmu keduanya sangat penting. Tetapi adab harus didahulukan daripada ilmu karena menurutnya agar ilmu yang diperoleh dapat menjadi berkah dan mempunyai tata karma di masyarakat. Dari noema yang dikemukakan, peneliti ingin mengembangkan epoche untuk mendapatkan kesadaran mendalam informan (noesis). Kemudian peneliti menanyakan terkait apakah ada praktik dalam kelas etika bisnis yang pernah dia tempuh. Dewi mengungkapkan: 


\section{Adab Menuntut Ilmu... \\ Firmansyah, N.I dan Mulawarman, A.D.}

"Ya dulu di kelas etika bisnis ada praktiknya juga. Praktik lapangan waktu dulu itu dilakukan satu kelas. Kita ramai-ramai mengumpulkan dana kemudian dana tersebut dibagi menjadi dua tempat untuk disalurkan. Yang pertama digunakan untuk membagikan makanan di jalan. Kemuadian yang kedua diberikan kepada panti asuhan berupa uang dan snack."

Dari pernyataan tersebut, Dewi mengungkapkan bahwa mata kuliah etika bisnis yang telah ditempuh oleh Dewi tidak hanya sebatas pada teori saja tetapi juga dibekali dengan praktik di lapangan. Dari pengalaman Dewi, ketika dia sedang menempuh mata kuliah etika bisnis tersebut, ada tugas untuk mengumpulkan dana yang akan digunakan untuk diberikan kepada orang yang membutuhkan. Misalnya yang pertama digunakan untuk membagikan makanan di jalan. Atau diberikan kepada panti asuhan yang membutuhkan berupa snack atau uang. Selanjutnya peneliti ingin menanyakan lebih mendalam bagaimanakah jika suatu perusahaan itu tidak mempraktikkan etika bisnis di dalam mereka melakukan kegiatan operasi bisnis mereka. Dewi menjawab:

"Akibatnya akan mengurangi kredibilitas perusahaan itu sendiri. Contohnya Telkomsel dulu pernah memanipulasi iklan Talkmania. Tetapi pelanggan Telkomsel merasa dirugikan karena iklan dan produk yang diterima tidak sesuai."

Intentional Analysis dari pernyataan yang diungkapkan oleh Dewi menunjukkan bahwa adab diperlukan terlebih dahulu karena untuk membentengi kita agar tidak melakukan perbuatan yang tidak etis ketika menjalankan sebuah bisnis. Kesadaran mendalam yang diungkapkan oleh Dewi (noesis) mengungkapkan bahwa praktik pelanggaran etika bisnis dapat merugikan perusahaan itu sendiri misalnya mengurangi kredibilitas perusahaan itu sendiri di mata pelanggannya. Dari noema dan noesis yang telah dikemukakan oleh Dewi, peneliti dapat mengabstraksikan (eidetic reduction) bahwa menurut Dewi adab dan ilmu keduanya sangat penting. Tetapi menurut Dewi adab harus didahulukan daripada ilmu. Hal ini dikarenakan ilmu yang diperoleh dapat diterima dengan baik oleh penuntut ilmu dan digunakan untuk kepentingan masyarakat secara luas. Selain itu materi tentang etika bisnis juga sangat penting untuk diterapkan dan tidak hanya sebagai teori saja. Menurut yang dipahami oleh Dewi jika suatu perusahaan itu tidak memiliki pengetahuan etika dalam berbisnis maka hal ini akan merugikan stakeholders lainnya misalnya pelanggan karena dirugikan.

Sementara itu Hafidz mengungkapkan adab dan ilmu kurang lebih sama dengan informan yang lainnya. Ketika peneliti menanyakan tentang lebih penting mana antara adab dan ilmu maka dia menjawab adab dan ilmu sama-sama penting, tetapi adab harus diprioritaskan terlebih dahulu: "keduanya penting, tapi kalau prioritas adab terlebih dahulu."

Dari pernyataan awal (noema) yang diungkapkan oleh Hafidz, peneliti menanyakan pertanyaan lagi untuk mendapatkan epoche terkait adab bagi para mahasiswa saat di kelas. Peneliti menanyakan apakah menurut pengamatan dan 


\title{
Oetoesan Hindia: Telaah Pemikiran Kebangsaan \\ Volume 2 No 2 Tahun $2020 \mathrm{Hlmn}$. 50-75
}

pengalamannya, mahasiswa sudah mempraktikkan adabnya dalam menuntut ilmu. Hafidz mengungkapkan:

\begin{abstract}
"Sekarang gini, kamu lihat aja realita di kelas. Ada dosen menjelaskan terus malah ada yang main HP, ngobrol sendiri atau malah ngomongin dosen lain. Masuk gak kira-kira ilmunya? Nah orang itu juga tidak beradab. Bukan para mahasiswa akuntansi UB sih. Sebagian besar yang beradab juga banyak. Mereka kuliah bukan untuk kepentingan sendiri. mereka kuliah rutinitas saja. Karena kalau untuk kepentingan sendiri pasti tenanan."
\end{abstract}

Sementara itu ketika peneliti ingin mengungkap lebih jauh kesadaran dari (noesis) Hafidz. Peneliti menemukan ungkapan yang berbeda dari ketiga informan lainnya. Peneliti menanyakan tentang seberapa penting mata kuliah etika bisnis itu bagi bekal mahasiswa kedepannya, dia mengungkapkan hal yang berbeda dari ketiga informan lainnya. Hafidz mengungkapkan:

"Enggak penting, mending les Bahasa Inggris aja. Jadi mata kuliah satu semester itu buang-buang waktu. ya bayangin aja kita dididik dengan pendidikan Indonesia dengan teks buku tentang moral. Eh ternyata banyak yang tidak bermoral. Itu semua yang ada di buku aku yakin tidak ada di Indonesia. Jadi mata kuliah satu semester itu buang-buang waktu aja. Mending untuk les Bahasa Inggris. Toh kalau kamu akhirnya sudah beretika, mayoritas orang lainnya tidak mengamalkan etikanya dengan baik."

Noesis Hafidz mengungkapkan bahwa mata kuliah etika bisnis kurang penting. Dia berpendapat bahwa pendidikan moral yang hanya dengan teks buku merupakan kegiatan yang tidak efektif. Menurutnya teori etika yang ada di buku tidak sepenuhnya dipraktikkan oleh masyarakat Indonesia. Dia juga mengungkapkan ketika kita sudah beretik, belum tentu mayoritas orang lainnya beretika seperti apa yang kita praktikkan. Intentional Analysis yang diungkapkan oleh Hafidz dari pernyataan di atas adalah adab yang baik merupakan sebuah perbuatan yang sangat penting. Dan adab yang baik harus dipraktikkan oleh mayoritas masyarakat agar dampaknya terasa. Dari noema dan noesis yang dipaparkan oleh Hafidz, peneliti dapat mengabstraksikan (eidetic reduction) bahwa menurut Hafidz adab dan ilmu merupakan suatu hal yang penting. Tetapi adab harus diprioritaskan terlebih dahulu. Hal ini dikarenakan dengan adab yang baik, ilmu yang diperoleh akan lebih meresap dan bermanfaat. Dan juga dari pengamatan dan pengalamannya, ketika seorang memiliki adab yang baik maka dia akan memerhatikan orang yang sedang berbicara di depannya dan tidak memainkan smartphone mereka bahkan mengobrol sendiri. Hafidz mengungkapkan bahwa mata kuliah etika bisnis itu kurang penting karena 


\section{Adab Menuntut Ilmu... Firmansyah, N.I dan Mulawarman, A.D.}

teori yang diajarkan tidak selaras dengan praktiknya. Dan dia juga berpendapat bahwa praktik etika yang baik harus dilakukan oleh mayoritas masyarakat agar dampaknya itu terasa, bukan hanya dari sedikit masyarakat.

Jawaban yang diungkapkan oleh masing-masing informan di atas sama, yaitu adab dan ilmu keduanya sangat penting. Tetapi untuk mendapatkan ilmu yang bermanfaat dan barokah maka sebelumnya diperlukanlah adab terlebih dahulu untuk mengambil ilmunya.

Adab Menuntut Ilmu bagi Calon Seorang Akuntan. Dalam wawancara antara peneliti dan informan terdapat bermacam-macam kesimpulan adab menuntut ilmu yang diungkapkan oleh setiap informan. Saat peneliti bertanya kepada Maulana terkait tujuannya dia memilih jurusan akuntansi disbanding jurusan lainnya, dia mengungkapkan: "Aku pilih karena prospek kerjanya emang lebih luas daripada jurusan lain.”

Dari pernyataan awal yang diungkapkan oleh Maulana (noesis), dia mengungkapkan bahwa dia memilih jurusan akuntansi karena prospek kerjanya yang lebih luas dibanding jurusan yang lainnya. Selanjutnya peneliti ingin mengembangkan pertanyaan lebih jauh (epoche). Untuk mengungkap adab menuntut ilmu dari Maulana, peneliti menanyakan tentang kebiasaannya sebelum perkuliahan dimulai. Menurut perspektif pemikiran HOS Tjokroaminoto, berdoa sebelum memulai suatu kegiatan merupakan adab yang baik bagi seorang muslim. Kemudian peneliti menanyakan mengenai kegiatan apa yang dilakukan sebelum perkuliahan di mulai. Maulana mengungkapkan:

"Kadang ngobrol sama temen atau biasanya baca-baca materi. Kalau berdoa sebelum kelas dimulai ya tergantung, kalau langsung ya ikutin aja.”

Dari pernyataan yang diungkapkan oleh Maulana, dia mengungkapkan bahwa sebelum memulai kelas biasanya Maulana mengobrol dengan temannya atau membaca materi yang akan diajarkan di kelas pada saat itu. Berikutnya peneliti menanyakan terkait perbuatan yang dilakukan oleh Maulana ketika dosen sedang mengajar atau dalam kata lain perkuliahan masih sedang berlangsung. Peneliti menanyakan apakah Maulana pernah membuka HP-nya ketika perkuliahan sedang berlangsung dana pa alasannya. Dia mengungkapkan:

"Pernah kalau lagi sibuk-sibuknya proker. Biasanya line atau WA, itu aja untuk memberitahu anggota lainnya kalau aku masih belum selesai kelasnya."

Dari ungkapan Maulana di atas, dia pernah membuka HP ketika perkuliahan masih berlangsung karena sedang mengikuti sebuah program kerja dari organisasi yang dia ikuti. Dia biasanya membuka HP pada saat itu untuk membalas dan memberitahu anggota lainnya bahwa dia masih ada kelas dan belum selesai. Untuk mendapatkan kesadaran yang lebih mendalam (noesis) dari Maulana, peneliti menanyakan mengenai perbuatan yang dia lakukan sebelum memulai sebuah kegiatan apakah 


\section{Oetoesan Hindia: Telaah Pemikiran Kebangsaan Volume 2 No 2 Tahun $2020 \mathrm{Hlmn}$. 50-75}

sudah sesuai dengan adab HOS Tjokroaminoto yang mana dalam segala aspek harus memiliki rasa menembah gusti. Maulana mengungkapkan: "Enggak bro, aku lebih sering lupa karena buru-buru."

Noesis Maulana mengungkapkan bahwa dia jarang berdoa terlebih dahulu sebelum memulai suatu kegiatan karena sering lupa dan buru-buru. Intentional analysis dari pernyataan-pernyataan yang diungkapkan oleh Maulana adalah perbuatan yang dilakukan Maulana saat di kelas maupun di luar kelas merupakan cerminan dari adab khususnya adab menuntut ilmu. Dari noema dan noesis yang diungkapkan oleh Maulana, peneliti dapat mengabstraksikan (eidetic reduction) bahwa Maulana merasa bahwa mengambil jurusan akuntansi saat kuliah merupakan pilihan yang baik karena prospek kerjanya yang luas. Pendapat Maulana sebagai bentuk kesadaran eksplisit (noema) ini dapat dihubungkannya dengan adabnya saat dia sedang menuntut ilmu dan juga pengalamannya ketika sedang menuntut ilmu pada akhirnya akan membentuk kesadaran yang lebih mendalam (noesis). Dari ungkapannya, sebelum kelas dimulai Maulana mengungkapkan bahwa dia biasanya mengobrol dengan teman sebangkunya atau membaca materi yang akan dibahas. Untuk berdoa sebelum memulai belajar di kelas Maulana mengikuti dosen. Jika berdoa terlebih dahulu maka dia mengikutinya dan begitu juga sebaliknya. Selain itu, dia juga pernah membuka HP saat perkuliahan masih berlangsung untuk membalas chat penting karena dia mengikuti proker. Untuk berdoa sebelum memulai suatu kegiatan, maulana mengungkapkan bahwa dia lebih sering tidak melakukan karena lupa dan terburu-buru.

Informan berikutnya adalah Hafidz. Peneliti ingin mengetahui adab menuntut ilmu dari Hafidz. Sebelum menanyakan lebih jauh tentang adab menuntut ilmu peneliti menanyakan terlebih dahulu tujuan mengapa Hafidz memilih jurusan akuntansi disbanding jurusan yang lainnya. Hafidz mengungkapkan: "Motivasiku saat itu yak arena jurusan akuntansi paling ketat dibanding jurusan lainnya."

Berdasarkan pendapat awalnya (noema), Motivasi Hafidz mengambil jurusan akuntansi dibanding jurusan lainnya karena menurutnya jurusan akuntansi paling ketat dari rumpun ilmu sosial dibanding jurusan lainnya dan ini menantang dia untuk masuk di jurusan ini. Selanjutnya untuk mengembangkan pertanyaan (epoche), peneliti menanyakan kegiatan apa yang dilakukan Hafidz sebelum kelas dimulai atau ketika menunggu dosen datang. Dan juga apakah dia berdoa terlebih dahulu sesuai dengan pemahaman adab dari HOS Tjokroaminoto yaitu rasa menembah gusti dalam segala aspek kehidupan yang dicerminkan dari adab menuntut ilmu dengan berdoa sebelum memulai pelajaran. Hafidz mengungkapkan: "baca-baca materi atau ngobrol sama temen. Sebelum memulai pelajaran kadang berdoa sendiri, kadang kalau dosennya langsung mulai ya udah jalan aja."

Dari pernyataan yang diungkapkan oleh Hafidz, dia mengungkapkan bahwa kegiatan yang dilakukannya ketika menunggu kelas dimulai adalah membaca materi yang akan dibahas nanti dan mengobrol dengan teman sebangkunya. Untuk kegiatan berdoa sebelum memulai pelajaran di kelas, Hafidz mengungkapkan bahwa dia 


\section{Adab Menuntut Ilmu... Firmansyah, N.I dan Mulawarman, A.D.}

terkadang berdoa sendiri atau jika dosennya langsung memulai langsung perkuliahannya maka dia mengikuti tanpa berdoa terlebih dahulu. berikutnya peneliti bertanya kepada Hafidz apakah dia pernah membuka HP-nya saat perkuliahan masih berlangsung dan mengapa dia melakukannya. Hafidz mengungkapkan: "Pernah pas di akhir-akhir mau selesai buka medsos. Tapi jarang sih.”

Dari ungkapan yang disampaikan oleh Hafidz, dia mengungkapkan bahwa dia pernah membuka HP-nya untuk membuka media sosialnya waktu kelas akan berakhir. Meskipun demikian, Hafidz jarang melakukan perbuatan tersebut. Untuk mendapatkan kesadaran yang lebih mendalam dari Hafidz, peneliti menanyakan lebih jauh (noesis) mengenai perbuatan yang dia lakukan sebelum melakukan suatu kegiatan. Apakah sudah sesuai dengan adab HOS Tjokroaminoto yang mengungkapkan bahwa dalam segala aspek harus disertai dengan rasa menembah gusti. Hafidz mengungkapkan: "mayoritas ya, tetapi kadang lupa sih kalau buruburu."

Kesadaran yang lebih mendalam (noesis) yang diungkapkan oleh Hafidz mengatakan bahwa dia biasanya berdoa terlebih dahulu ketika akan memulai sebuah kegiatan. Tetapi terkadang dia juga lupa untuk berdoa dikarenakan dia sedang buruburu. Intentional analysis dari pernyataan-pernyataan yang diungkapkan oleh Hafidz adalah perbuatan yang dilakukan Hafidz saat di kelas maupun di luar kelas merupakan cerminan dari adab khususnya adab menuntut ilmu. Dari noema dan noesis yang diungkapkan oleh Hafidz, peneliti dapat mengabstraksikan (eidetic reduction) bahwa Hafidz merasa bahwa memilih jurusan akuntansi untuk kuliah merupakan pilihan yang Hafidz buat karena seleksi masuk untuk jurusan akuntansi sangat ketat. Pendapat Hafidz sebagai bentuk kesadaran eksplisit (noema) ini dapat dihubungkannya dengan adabnya saat dia sedang menuntut ilmu dan juga pengalamannya ketika sedang menuntut ilmu pada akhirnya akan membentuk kesadaran yang lebih mendalam (noesis). Dari ungkapannya, sebelum kelas dimulai Hafidz mengungkapkan bahwa dia biasanya mengobrol dengan temannya atau membaca materi yang akan dibahas di kelas nanti. Untuk berdoa sebelum memulai belajar di kelas Hafidz mengikuti dosen. Jika berdoa terlebih dahulu maka dia mengikutinya dan begitu juga sebaliknya. Selain itu, dia biasanya juga pernah membuka HP saat perkuliahan masih berlangsung di saat kelas akan berakhir, tetapi itu jarang dilakukan oleh Hafidz. Untuk berdoa sebelum memulai suatu kegiatan, Hafidz mengungkapkan bahwa dia lebih sering tidak melakukannya karena lupa dan terburu-buru.

Informan berikutnya adalah Dewi. Peneliti ingin mengungkap adab menuntut ilmu dari Dewi. Tetapi sebelum melangkah lebih jauh peneliti ingin mengetahui alasan Dewi memilih jurusan akuntansi saat kuliah dibanding jurusan yang lain. Dewi mengungkapkan:

"Tujuan kuliah di jurusan akuntansi alasannya agar mendapat pekerjaan. karena bidang akuntansi banyak peminatnya dan sering banget lihat banyak lowongan pekerjaan." 


\section{Oetoesan Hindia: Telaah Pemikiran Kebangsaan \\ Volume 2 No 2 Tahun $2020 \mathrm{Hlmn}$. 50-75}

Dari pernyataan awal yang diungkapkan oleh Dewi (noema), mengungkapkan bahwa tujuannya mengambil jurusan akuntansi karena ingin mendapatkan pekerjaan. Hal ini dikarenakan, menurutnya jurusan akuntansi memiliki prospek kerja yang sangat luas dan sangat banyak lowongan di bidang akuntansi. Selanjutnya peneliti mengembangkan pertanyaan (epoche) untuk memperdalam pengungkapan dari kesadaran informan. Peneliti menanyakan tentang kegiatan apa yang dilakukan oleh Dewi ketika menunggu kelas dimulai dan perbuatan apa yang akan dilakukan oleh Dewi saat sebelum dosen menerangkan di depan kelas. Pertanyaan ini dirasa penting oleh peneliti karena peneliti ingin mengungkap pemahaman adab mahasiswa akuntansi FEB UB menururt perspektif HOS Tjokroaminoto, yaitu rasa menembah gusti dalam segala aspek terutama menuntut ilmu bagi mahasiswa. Dewi mengungkapkan:

"Yang aku lakukan pada saat menunggu dosen, biasanya belajar sedikit lewat internet apa yang mau dipelajari, kadang juga ngobrol. Untuk berdoa kadang berdoa kalau ingat atau kalau dosennya mengingatkan. Kalau langsung belajar aku lupa gak doa."

Dari pernyataan yang diungkapkan oleh Dewi, dia mengungkapkan bahwa dia biasanya membaca literatur materi yang akan dibahas di kelas itu terlebih dahulu ketika dia sedang menunggu dosen datang. Untuk berdoa sebelum memulai belajar, Dewi mengungkapkan bahwa dia mengikuti dosen, jika diawali dengan berdoa terlebih dahulu maka dia mengikuti, tetapi jika tidak maka dia langsung mengikuti perkuliahan. Selanjutnya peneliti mencoba bertanya terkait media sosial. Peneliti menanyakan apakah Dewi pernah membuka HP-nya ketika perkuliah sedang berlangsung. Dia mengungkapkan:

"Pernah membuka HP kalau misalkan dosennya yang memberi instruksi buat cari referensi, pernah juga buka HP diem-diem buat sosmed."

Pernyataan Dewi di atas menunjukkan bahwa dia pernah membuka HP saat perkuliahan sedang berlangsung. Dewi mengungkapkan bahwa hal ini dilakukan karena dosen menyuruh mahasiswanya untuk mencari literatur materi di internet. Selain itu dia mengungkapkan bahwa dia juga pernah membuka HP-nya untuk membuka media sosialnya. Pertanyaan berikutnya untuk memperdalam pernyataan yang diungkapkan oleh Dewi (noesis), peneliti menanyakan apakah dia berdoa terlebih dahulu sebelum melakukan sebuah aktivitas atau kegiatan yang mana itu merupakan adab menurut perspektif HOS Tjokroaminoto, yaitu rasa menembah gusti disegala aspek kehidupan. Dewi mengungkapkan: "Kadang-kadang berdoa jika ingat, kalau gak ingat langsung melakukan aktivitas."

Noesis yang diungkapkan oleh Dewi mengatakan bahwa sebelum melakukan suatu aktivitas atau kegiatan, dia terkadang berdoa terlebih dahulu dan terkadang 


\section{Adab Menuntut Ilmu... \\ Firmansyah, N.I dan Mulawarman, A.D.}

tidak karena dia lupa. Intentional analysis dari pernyataan-pernyataan yang diungkapkan oleh Dewi adalah perbuatan yang dilakukan Dewi saat di kelas maupun di luar kelas merupakan cerminan dari adab khususnya adab menuntut ilmu. Dari noema dan noesis yang diungkapkan oleh Dewi, peneliti dapat mengabstraksikan (eidetic reduction) bahwa Dewi merasa bahwa mengambil jurusan akuntansi untuk kuliah merupakan pilihan yang Dewi pilih karena prospek kerja yang sangat luas. Pendapat Dewi sebagai bentuk kesadaran eksplisit (noema) ini dapat dihubungkannya dengan adabnya saat dia sedang menuntut ilmu dan juga pengalamannya ketika sedang menuntut ilmu pada akhirnya akan membentuk kesadaran yang lebih mendalam (noesis). Dari ungkapannya, sebelum kelas dimulai Dewi mengungkapkan bahwa dia biasanya membaca literatur materi yang akan dibahas di kelas nanti. Untuk berdoa sebelum memulai belajar di kelas Dewi mengikuti dosen. Jika berdoa terlebih dahulu maka dia mengikutinya dan begitu juga sebaliknya. Selain itu, dia biasanya juga pernah membuka HP saat perkuliahan masih berlangsung untuk membalas chat penting. Untuk berdoa sebelum memulai suatu kegiatan, Dewi mengungkapkan bahwa dia lebih sering tidak melakukannya karena lupa.

Informan terakhir yang ingin diungkap oleh peneliti terkait adab menuntut ilmu menurut perspektif HOS Tjokroaminoto adalah Ahmad. Pertama-tama peneliti menanyakan alasan Ahmad masuk di jurusan akuntansi daripada jurusan lainnya. Ahmad mengungkapkan:

"Sewaktu SMA suka dengan mata pelajaran akuntansi dan aku memiliki pandangan positif terhadap prospek karir akuntansi waktu itu."

Pendapat awal yang diungkapkan oleh Ahmad (noema) mengatakan bahwa tujuan dia memilih jurusan akuntansi karena akuntansi merupakan pelajaran yang menjadi kesukaannya di SMA pada saat itu. Dan dia berpendapat bahwa prospek kerja dari lulusan jurusan akuntansi itu besar. Dari pernyataan ini peneliti mengembangkan pertanyaan (epoche) untuk memperoleh kesadaran yang lebih mendalam. Selanjutnya peneliti menayakan terkait perbuatan yang dilakukan Ahmad di kelas ketika sedang menunggu dosen datang dan apakah Ahmad berdoa terlebih dahulu sebelum kelas akan segera dimulai. Ahmad mengungkapkan:

"Saat menunggu dosen datang biasanya membuka literatur materi yang nanti akan dibahas atau terkadang membuka medsos di HP kalau bosen. Ya aku rutin berdoa sebelum belajar (secara pribadi). Misal doa seperti Rabbisyrahli shadri atau Rabbi zidni ilma."

Dari pernyataan yang diungkapkan oleh ahmad, dia mengungkapkan bahwa saat sedang menunggu dosen datang, perbuatan yang dia lakukan biasanya adalah membuka literature materi yang nanti akan dibahas di kelas dan membuka medsos di HP ketika sedang bosan. Meskipun demikian Ahmad tergolong mahasiswa yang berakhlak mulia. Hal ini tercermin dari pernyataannya di atas, yaitu dia secara pribadi sering berdoa ketika akan memulai kegiatan belajar. Selanjutnya peneliti 


\section{Oetoesan Hindia: Telaah Pemikiran Kebangsaan Volume 2 No 2 Tahun $2020 \mathrm{Hlmn}$. 50-75}

bertanya mengenai perbuatan yang dilakukan Ahmad ketika pembelajaran sedang berlangsung. Apakah dia pernah memainkan HP-nya saat dosen sedang menerangkan ataukah tidak. Ahmad mengungkapkan:

"Pernah, ketika temen-temen mahasiswa pada presentasi, Aku biasanya lihat literatur karena kurang jelas dengan materinya. Tapi kalau dengan dosen gak pernah aku."

Pernyataan Ahmad di atas mengungkapkan bahwa dia pernah membuka HP saat perkuliahan masih sedang berlangsung. Dia membuka HP ketika temantemannya sedang presentasi di depan kelas. Meskipun demikian dia tidak pernah membuka HP ketika yang berbicara di depan itu seorang dosen. Terakhir peneliti ingin bertanya lebih mendalam kepada Ahmad untuk mendapatkan kesasdaran yang lebih mendalam (noesis). Peneliti menanyakan mengenai apakah dia sering berdoa sebelum memulai suatu aktivitas kegiatan. Ahmad mengungkapkan: "Ya, sudah biasa itu. Biasanya saat makan, masuk toilet, memulai sesuatu, perjalanan, dan lain lain.”

Dari noesis yang diungkapkan oleh Ahmad, dia mengungkapkan bahwa dia sudah terbiasa untuk berdoa terlebih dahulu sebelum memulai suatu aktivitas kegiatan. Intetntional analysis dari pernyataan-pernyataan yang diungkapkan oleh Ahmad adalah perbuatan yang dilakukan Ahmad saat di kelas maupun di luar kelas merupakan cerminan dari adab khususnya adab menuntut ilmu. Dari noema dan noesis yang diungkapkan oleh Ahmad, peneliti dapat mengabstraksikan (eidetic reduction) bahwa Ahmad merasa bahwa mengambil jurusan akuntansi untuk kuliah merupakan pilihan yang tepat karena prospek kerja yang sangat luas.

Pendapat Ahmad sebagai bentuk kesadaran eksplisit (noema) ini dapat dihubungkannya dengan adabnya saat dia sedang menuntut ilmu dan juga pengalamannya ketika sedang menuntut ilmu pada akhirnya akan membentuk kesadaran yang lebih mendalam (noesis). Dari ungkapannya, sebelum kelas dimulai Ahmad mengungkapkan bahwa dia biasanya membaca literatur materi yang akan dibahas atau dia biasanya juga membuka medso di HP-nya ketika menunggu dosen. Untuk berdoa sebelum memulai belajar di kelas, Ahmad mengungkapkan bahwa dia selalu berdoa terlebih dahulu karena perbuatan itu sudah menjadi kebiasaannya. Meskipun demikian, dia juga pernah membuka HP saat perkuliahan masih sedang berlangsung, tetapi itu dilakukan sewaktu mahasiswa sedang presentasi di kelas bukan ketika dosen sedang menerangkan di depan kelas. Untuk berdoa sebelum memulai suatu aktivitas kegiatan, Ahmad mengungkapkan bahwa dia sudah terbiasa melakukannya.

Dari tabel terlihat bahwa ada informan yang sudah menerapkan rasa Menembah Gusti dalam setiap fase. Disamping itu, ada juga informan yang masih belum mengamalkannya secara utuh. Ahmad merupakan informan yang sudah mengamalkan secara sempurna. Dia mengamalkan dalam setiap fasenya rasa menembah Gusti. Selain itu, ketiga informan lainnya masih belum secara keseluruhan 


\section{Adab Menuntut Ilmu... \\ Firmansyah, N.I dan Mulawarman, A.D.}

mengamalkannya. Dari situ dapat dilihat dalam tabel, Hafidz sudah melalui fase satu dan dua. Akan tetapi dalam fase ketiga, dia belum mengamalkan adab sebelum ilmu dana dab dalam segala aktivitas kegiatan. Sementara itu Dewi dan Maulana sudah melewati fase satu dan dua, akan tetapi mereka pada fase yang ketiga masih belum mengimplementasikan secara keseluruhan poin-poin dalam fase yang ketiga ini.

Tabel 1. Analisis adab menuntut ilmu melalui rasa Menembah Gusti

\begin{tabular}{llllll}
\hline & Fase 1 & Fase 2 & Fase 3 & & \\
\cline { 2 - 6 } & $\begin{array}{l}\text { Mengetahui } \\
\text { HOS } \\
\text { Tjokroaminoto }\end{array}$ & $\begin{array}{l}\text { Konsep } \\
\text { Adab } \\
\text { Sebelum } \\
\text { Ilmu }\end{array}$ & $\begin{array}{l}\text { Adab } \\
\text { Sebelum } \\
\text { Ilmu }\end{array}$ & $\begin{array}{l}\text { Adab } \\
\text { dalam } \\
\text { berilmu }\end{array}$ & $\begin{array}{l}\text { Adab } \\
\text { segala } \\
\text { aktivitas } \\
\text { kegiatan }\end{array}$ \\
\hline Ahmad & $\checkmark$ & $\checkmark$ & $\checkmark$ & $\checkmark$ & $\checkmark$ \\
\hline Hafidz & $\checkmark$ & $\checkmark$ & x & $\checkmark$ & x \\
\hline Dewi & $\checkmark$ & $\checkmark$ & x & x & x \\
\hline Maulana & $\checkmark$ & $\checkmark$ & x & x & x \\
\hline
\end{tabular}

Untuk menjadi insan yang baik dan beradab maka keseluruhan fase harus dilewati dengan sempurna. Artinya konsep dan implementasinya harus sejalan. Jadi adab atau etika itu tidak hanya sebagai ilmu saja, dalam artian sebagai konsep saja. Tetapi juga sebagai laku. Etika sebagai laku artinya etika tersebut diimplementasikan/dipraktikkan dalam kehidupan sehari-hari. Jika adab yang dimiliki mahasiswa itu baik maka tujuan pendidikan akuntansi yang mana bertujuan untuk memberikan nilai-nilai pencerahan dan pembebasan (tazkiyah) serta nilai tambah (value added) dari hegemoni korporasi pendidikan yang bersifat egoistis untuk kepentingan shareholders dan market dalam bentuk sinergi akuntabilitas-moralitas akan tercapai (Mulawarman, 2008). Dalam kalimat yang lebih sederhana, tujuan dari pendidikan akuntansi adalah untuk menjadikan mahasiswa memiliki nilai-nilai ketuhanan (kecerdasan spiritual) dan meningkatkan perbuatan moral baik mereka (kecerdasan emosional) disamping meningkatkan kemampuan teknis mereka di bidang akuntansi (kecerdasan intelektual). Dengan demikian, mahasiswa diharapkan mampu untuk mengintegrasikan akuntabilitas dan moralitas itu tidak hanya kepada stockholders, tetapi lebih kepada masyarakat dan lingkungan.

Ketika mahasiswa dibekali dengan adab yang baik maka saat mereka sudah lulus dan mulai masuk ke dunia kerja atau bisnis, mereka akan memerhatikan perbuatan yang mereka lakukan etis atau tidak meskipun itu dapat menguntungkan perusahaan dengan laba yang besar. Adab menuntut ilmu adalah dasar bagi karyawan/pekerja/pengusaha untuk dapat memerhatikan etika bisnis secara lebih. Karena etika mereka dalam berbisnis salah satu landasannya adalah adab mereka sewaktu menempuh dibangku sekolah/perkuliahan. Jika mereka tidak memerhatikan etika bisnis maka pelanggaranpun tidak bisa dielakkan. Misalnya kasus Enron dan KAP Arthur Andersen; manipulasi laba atau informasi; perusahaan yang ingin 


\section{Oetoesan Hindia: Telaah Pemikiran Kebangsaan \\ Volume 2 No 2 Tahun $2020 \mathrm{Hlmn}$. 50-75}

mengembangkan usahaanya tanpa mempedulikan lingkungan sekitar; produk yang spesifikasinya lebih rendah dari yang diiklankan; dan masih banyak kasus pelanggaran lainnya. Dari contoh tersebut langkah paling awal yang harus dibenahi adalah adab saat mereka masih menuntut ilmu. Dengan adab yang baik maka etika bisnis akan menjadi laku (diimplementasikan). Dengan lakunya etika bisnis maka pelanggaran akan berkurang.

\section{Simpulan}

Techne telah menubuh (embodied) pada setiap individu. Dalam hal ini techne yang dimaksud adalah smartphone (media sosial: WA, FB, dll). Hal ini senada seperti yang diungkapkan oleh masing-masing informan. Mereka mengungkapkan perilaku atau aktivitas kegiatan mereka melalui media sosial. Seperti Ahmad yang hobi mendesain, dia mengunggah karya desainnya di media sosial. Hafidz yang menyukai kutipan kalimat-kalimat motivasi yang selalu membagikannya di media sosial. Rifqi dan Dewi yang membagikan pengalamannya melalui media sosial.

Adab menuntut ilmu mahasiswa akuntansi FEB UB berbasis konsep menembah Gusti menurut pemikiran HOS Tjokroaminoto dalam penelitian ini ada tiga fase. Fase yang pertama adalah pengenalan dari tokoh HOS Tjokroaminoto, fase yang kedua adalah konsep dari adab dan ilmu, dan fase yang ketiga adalah implementasi dari konsep menembah Gusti. Fase yang pertama ini adalah pengetahuan informan terkait HOS Tjokroaminoto dan moral apa yang dapat dipetik dari beliau. Fase yang kedua adalah konsep adab dan ilmu berbasis rasa menembah Gusti. Dan fase yang ketiga adalah implementasi dari adab menuntut ilmu berbasis rasa menembah Gusti. Dalam fase ketiga ini ada tiga poin yang digali oleh peneliti. Yang pertama adalah adab sebelum memulai pembelajaran di kelas. Yang kedua adalah adab ketika sedang belajar di kelas. Yang terakhir adalah adab dalam segala aktivitas kegiatan.

Dari ketiga fase tersebut hanya Ahmad yang dapat melalui semua tahapannya. Sementara itu dari ketiga informan lainnya hanya mampu melewati fase yang pertama dan kedua saja. Untuk fase yang ketiga Dewi dan Maulana masih belum menerapkannya. Sementara itu Hafidz hanya menerapkan poin yang kedua, yaitu adab ketika sedang belajar.

Dari hasil analisis dalam bab pembahasan tabel adab menuntut ilmu dari keempat informan tersebut maka dapat ditarik kesimpulan bahwa tujuan dari pendidikan akuntansi belum berhasil tercapai secara sempurna sebatas dari keempat informan tersebut. Hal ini dikarenakan dari keempat informan tersebut hanya Ahmad yang sudah menjalankan semua fase dengan baik, sementara itu ketiga informan lainnya hanya menjalankan konsepnya saja dan masih belum menerapkan implementasinya secara sempurna. Meskipun mereka memiliki pemahaman mengenai konsep adab atau etika yang baik, tetapi belum tentu dalam implementasinya mereka praktikkan. 


\section{B. If}

Adab Menuntut Ilmu...

Firmansyah, N.I dan Mulawarman, A.D.

Al-Attas. 1996. Konsep Pendidikan Dalam Islam (Haidar Bagis, Penerjemah). Bandung: Mizan.

Anonim. 2008. Telkomsel Dituding Rugikan Pelanggan Miliaran Rupiah. Diakses dari website https://inet.detik.com/telecommunication/d-1010207/telkomsel-ditudingrugikan-pelanggan-miliaran-rupiah

Anonim. 2012. Sejumlah Siswa Tertangkap Mencontek. Diakses dari website www.liputan6.com: https://www.liputan6.com/news/read/389459/sejumlah-siswatertangkap-mencontek.

Bertens, Kees. 2000. Pengantar Etika Bisnis. Yogyakarta: Kanisius.

Chwastiak, M., dan J. J. Young. 2003. Silences in Annual Reports. Critical Perspectives on Accounting 14: 553-552.

Dwiningrum, S. I. A. (2012). Ilmu Sosial \& Budaya Dasar. Yogyakarta. UNY Press.

Goleman, Daniel. 2003. Emotional Intelligence. Jakarta: Gramedia Pustaka Utama.

Hampton, Keith N. 2011. Social Networking Sites and Our Lives. Diakses dari website www.pewresearch.org: https://www.pewresearch.org/internet/2011/06/16/socialnetworking-sites-and-our-lives-2/

Kamayanti, Ari. 2017. Metodologi Penelitian Kualitatif Akuntansi. Jakarta: Yayasan Rumah Peneleh.

Kamayanti, Ari. Cinta: Tindakan Berkesadaran Akuntan (Pendekatan Dialogisdalam Pendidikan Akuntansi). Makalah Simposium Nasional 2012, hal 1-23.

Kurniawan, Rivan. 2018. Studi Kasus Enron: Bisakah Laporan Keuangan Dimanipulasi? . Diakses dari website www.finansialku.com/enron-corporationmanipulasi-laporan-keuangan/

Ludigdo, Unti. 2007. Paradoks Etika Akuntan.Yogyakarta: Pustaka Pelajar.

Ludigdo, Unti. 2010. Pembelajaran Etika Bisnis dan Profesi berbasis Integrasi IESQ. Makalah Karya Inovasi Unggul Ketua Jurusan Perguruan Tinggi Negeri Tingkat Nasional. Jakarta. Kementrian Pendidikan Nasional.

Madura, Jeff. 2007. Pengantar Bisnis. Jakarta : Salemba Empat.

Mathews, M.R. dan M.H.B. Parera. 1996. Accounting Theory and Development. International Thompson Publishing Company. South Melbourne.

Moleong, Lexy J. 2005. Metodologi Penelitian Kualitatif. Bandung: PT Remaja Rosdakarya.

Moneva, J. M., P. Archel, dan C. Correa. 2006. GRI and the Camouflaging of Corporate Unsustainability. Accounting Forum 30: 121-137.

Morgan, G. 1988. "Accounting as reality construction: towards a new epistemology for accounting practice". Accounting, Organizations and Society. Vol 13, No 5, hal 477485.

Mulawarman, Aji Dedi. 2008. "Pendidikan Akuntansi Berbasis Cinta: Lepas dari Hegemoni Korporasi Menuju Pendidikan yang Memberdayakan danKonsepsi Pembelajaran yang Melampui”. Ekuitas, Volume 12 Nomor 2,pp 142-145. 


\section{Oetoesan Hindia: Telaah Pemikiran Kebangsaan}

Volume 2 No 2 Tahun $2020 \mathrm{Hlmn}$. 50-75

Mulawarman, Aji Dedi dan Unti, Lundigdo. 2010. Metamorfosis Kesadaran Etis Holistik Mahasiswa Akuntansi Implementasi Pembelajaran Etika Bisnis dan Profesi Berbasis IESQ. Jurnal Akuntansi Multiparadigma (Vol. 1, Nomor 3, Desember 2010, 429-444).

Mulawarman, Aji Dedi. 2014. Akuntansi Tjokro-an Kritis ala HOS Tjokroaminoto. Ekonomika Jurnal Paradigma Islam di Bidang keuangan, Ekonomi dan Pembangunan.

Mulawarman, Aji Dedi. 2015. Jang Oetama: Jejak dan Perjuangan H.O.S Tjokroaminoto. Galang Press. Yogyakarta.

Mulawarman, Aji Dedi. (Ed.).(2019). Memeriksai Alam Kebenaran. Jakarta: Yayasan Rumah Peneleh.

Sanders, P. 1982. "Phenomenology: A New Way of Viewing Organizational Research". Academy of Management Review. Vol 7, No3, hal 353-360.

Salam, Burhanuddin. (2012). Etika Individual: Pola Dasar Filsafat Moral. Jakarta: Rineka Cipta.

Siregar, Ade rahmawati. (2006). Motivasi Berprestasi Mahasiswa Ditinjau Dari Pola Asuh. Diakses dari http:repository.usu.ac.id/handle/123456789/7334

Soejono Soemargono. 1983. Filsafat Pengetahuan. Yogyakarta: Nur Cahaya

Sugiyono. 2011. Metode Penelitian Kuantitatif, Kualitatif dan R\&D. Bandung: Afabeta.

Triyuwono, Iwan. 2001. Metafora Zakat dan Syari'ah ET sebagai konsep Dasar dalam Membentuk Akuntansi Syariah. Jurnal Akuntansi dan Auditing Indonesia. Volume 5, Nomer 2, hal 131-145

Triyuwono, I. 2009. Perspektif, Metodologi, dan Teori Akuntansi Syariah. Jakarta: Rajawali Press.

Triyuwono, Iwan. 2010. Mata Ketiga: Se Laen Sang Pembebas Sistem Pendidikan Tinggi Akuntansi. Jurnal Akuntansi Multiparadigma. Volume 1, Nomor 1, Hal 123.

Triyuwono, Iwan. 2011. Mengangkat "Sing Liyan" Untuk Formulasi Nilai Tambah Syari'ah. Jurnal Akuntansi Multiparadigma. Volume 2, Nomor 2, Hal 186-200.

Tuasikal, Muhammad Abduh. (2014). Pelajarilah dahulu adab dan akhlak. Diakses dari website www.muslim.or.id: https://muslim.or.id/21107-pelajarilah-dahuluadab-dan -akhlak.html

Undang-Undang Republik Indonesia Nomor 12 Tahun 2012 tentang Pendidikan Tinggi 